\title{
ISSUES IN RESEARCH \\ Protection of human participants in health research - a comparison of some US federal regulations and South African research ethics guidelines
}

\author{
P Cleaton-Jones, D Wassenaar
}

\begin{abstract}
In response to criticism of ethical review of a South African clinical trial, we contrast aspects of the United States Common Rule with South African research ethics requirements. In the USA the Common Rule does not apply to all health research and allows many exemptions from ethics review and waivers of informed consent. At a structural level research ethics review in South Africa is in many cases equivalent to the US institutional review board (IRB) and Office for Human Research Protections (OHRP) oversight system, is wider reaching, and has no exclusions.
\end{abstract}

\section{Introduction}

Philpott and Schüklenk posted a blog on the website of the Bioethics Forum of the Hastings Centre ${ }^{1}$ criticising a clinical trial in South Africa published in February 2010 in the New England Journal of Medicine. ${ }^{2}$ They had concerns with the trial, believing that it violated both '... ethical study design .... and '... the Declaration of Helsinki's requirements on standards of care ....1 Thereafter an article in Science ${ }^{3}$ commented on pros and cons of the trial and criticism of the trial and the arguments of Philpott and Schüklenk. ${ }^{1}$

Comments by Philpott and Schüklenk of concern to us regarding ethical review of the trial are: ${ }^{1}$

- '... serious concerns about the quality of ethical review in developing countries like South Africa ...

- 'Organisations ... have directed millions of dollars to train members of African ethical review committees and yet this trial was reviewed and approved by a committee in South Africa.'

- '... some surprising deficiencies in existing US regulations regarding when ethical review should be undertaken by American IRBs ....

Another paper ${ }^{4}$ critical of the same study in the New England Journal of Medicine ${ }^{2}$ also recommends revision of the South African ethics review system, and in particular suggests that international assistance should be sought, especially for interventional studies, in

Peter Cleaton-Jones is a dentist and medical practitioner who was Director of the Dental Research Institute at the University of the Witwatersrand before retirement. He is currently an Honorary Adjunct Professor in the Steve Biko Centre for Bioethics and since 1985 has been Chair of the Human Research Ethics Committee (Medical).

Doug Wassenaar is a clinical psychologist and Associate Professor in the School of Psychology at the University of KwaZulu-Natal. He is also Chair of the Biomedical Ethics Committee of the University of KwaZulu-Natal and directs the South African Research Ethics Training Initiative (SARETI). the hope that ethical problems would be more adequately identified before approval.

The authors of the present paper both chair research ethics committees (RECs) in South Africa that are registered with the South African National Health Research Ethics Council (see http://www. doh.gov.za/nhrec/) and have US Federalwide Assurance with the US OHRP (see http://www.hhs.gov/ohrp/assurances/assurances_index. html). DW also directs the South African Research Ethics Training Initiative (SARETI), a US NIH-Fogarty International Centersponsored master's-level research ethics training programme for REC members and researchers from African countries.

We are concerned about the insinuation that research ethics review and training in research ethics are substandard in South Africa. This could adversely affect perceptions of existing and potential international research collaborators from the USA and other developed countries. We therefore provide background on research ethics review and training in South Africa based on our approximately 50 years of experience in research ethics, and highlight some differences between South African and US federal guidelines on research ethics.

\section{History of research ethics committees in South Africa}

Beecher's 1966 article in the New England Journal of Medicine ${ }^{5}$ had an effect in South Africa, as elsewhere in the world. In 1996, having read Beecher's views, John Hansen, professor of paediatrics at the University of the Witwatersrand, persuaded his university to set up an REC based in the medical faculty, which has functioned continuously ever since. From 1977 onwards other universities in South Africa, the Department of Health (DOH), the Human Sciences Research Council (HSRC), the Medical Research Council (MRC), the pharmaceutical industry, the South African Medical Association, and bodies such as individual hospitals formed RECs (Table I). The MRC was the first to issue South African guidelines on ethics in health research, ${ }^{6}$ followed by the $\mathrm{DOH}^{7}$ and the $\mathrm{HSRC}^{8}$ (Table I). This timeline is similar to organisations elsewhere, e.g. the US National Institutes of Health, ${ }^{9}$ particularly after the publication of the Belmont Report in the USA ${ }^{10}$ (Table II).

Initially, compliance with ethical clearance of health research was a moral decision for South African researchers, reinforced by internal regulations of the various institutions mentioned above. This changed in 1996 with the passing into law of the South African Constitution, which states:

'... Everyone has the right to bodily and psychological integrity, which includes the right:

a) to make decisions concerning reproduction;

b) to security in and control over their body; and

c) not to be subjected to medical or scientific experiments without their informed consent.'11

This entrenchment of informed consent in a national constitution is the only one in the world.

The National Health Act became law in 2005, making the prior ethical approval of research by a registered REC a legal requirement. ${ }^{12}$ 
Table I. Timeline for research ethics in South Africa

\begin{tabular}{|c|c|}
\hline Year & Comment \\
\hline 1966 & $\begin{array}{l}\text { June - Beecher's NEJM article } \\
\text { October - University of the Witwatersrand forms } \\
\text { REC }\end{array}$ \\
\hline $1977+$ & South African universities and MRC form RECs \\
\hline 1979 & $\begin{array}{l}\text { SA MRC issues research ethics guidelines (revised } \\
1987,1993,2002-2005 \text { ) }\end{array}$ \\
\hline 1992 & SAMA establishes REC \\
\hline 1995 & Pharma ethics REC established \\
\hline 1996 & $\begin{array}{l}\text { SA Constitution entrenches informed consent to } \\
\text { participate in research in Bill of Rights }\end{array}$ \\
\hline 2000 & $\begin{array}{l}\text { SA DoH issues clinical trial GCP guidelines } \\
\text { (revised 2006) }\end{array}$ \\
\hline 2004 & $\begin{array}{l}\text { SA DoH issues research ethics guidelines } \\
\text { US OHRP does quality assurance site visits at } 6 \text { SA } \\
\text { university RECs }\end{array}$ \\
\hline 2005 & $\begin{array}{l}\text { National Health Act No. } 61 \text { of } 2003 \text { makes REC } \\
\text { approval compulsory }\end{array}$ \\
\hline 2006 & $\begin{array}{l}\text { SA National Health Research Ethics Council } \\
\text { established }\end{array}$ \\
\hline 2008 & $\begin{array}{l}\text { Compulsory registration of SA RECs with NHREC } \\
\text { DoH public list of clinical trials compulsory }\end{array}$ \\
\hline 2010 & Audit of SA RECs by NHREC \\
\hline \multicolumn{2}{|c|}{$\begin{array}{l}\text { MRC = Medical Research Councili, REC = research ethics committee; SAMA = South } \\
\text { African Medical Association; DoH = National Department of Health; GCP = good clini } \\
\text { cal practice; NHREC = National Health Research Ethics Council. }\end{array}$} \\
\hline
\end{tabular}

The Act also defines a National Health Research Ethics Council (NHREC) with the following duties:

'72...

(6) The National Health Research Ethics Council must -

(a) determine guidelines for the functioning of health research ethics committees;

(b) register and audit health research ethics committees;

(c) set norms and standards for conducting research on humans and animals, including norms and standards for conducting clinical trials;

(d) adjudicate complaints about the functioning of health research ethics committees and hear any complaint by a researcher who believes that he or she has been discriminated against by a health research ethics committee;

(e) refer to the relevant statutory health professional council matters involving the violation or potential violation of an ethical or professional rule by a health care provider;

(f) institute such disciplinary action as may be prescribed against any person found to be in violation of any norms and standards, or guidelines, set for the conducting of research in terms of this Act; and

( $g$ ) advise the national department and provincial departments on any ethical issues concerning research ....12

This Council is the equivalent of the US OHRP ${ }^{13}$ but has wider reach and greater powers. There are important differences between the US OHRP's reach and that of the SA NHREC. 'The OHRP has
Table II. Evolution of ethics review in the USA ${ }^{9}$

\begin{tabular}{ll}
\hline Year & Comment \\
\hline 1953 & $\begin{array}{l}\text { NIH intramural clinical research to be screened by } \\
\text { Protection of Human Subjects Review Panel }\end{array}$ \\
1966 & $\begin{array}{l}\text { June - Beecher's NEJM article } \\
\text { US Public Health Service IRB system established, } \\
\text { screening extended to extramural research }\end{array}$ \\
1974 & $\begin{array}{l}\text { National Research Act, IRB screening of all } \\
\text { research, human research regulations 45 CFR 46 } \\
\text { developed }\end{array}$ \\
1979 & $\begin{array}{l}\text { Belmont Report, national legal requirement for IRB } \\
\text { review }\end{array}$ \\
1981 & $\begin{array}{l}\text { Health and Human Services provided framework } \\
\text { for IRB function and revision of 45 CFR 46 } \\
1981 \text { - 2009 }\end{array}$ \\
Intermittent revision of 45 CFR 46 \\
IRB = institutional review board.
\end{tabular}

jurisdiction over research funded by or supported by the Department of Health and Human Services, for research conducted either in the US or in other countries. For research that is funded or conducted by DHHS within the US, institutions may voluntarily decide to apply the Common Rule ${ }^{14}$ to all research, regardless of funding source (E Bartlett, personal communication, 1 July 2010). A similar situation prevails in Canada. ${ }^{15}$ This voluntary use of the Common Rule for non-federally funded research implies to us that regulation and ethics oversight of non-federally funded research in the USA are not subject to any statutory, nationally monitored supervision. This system regarding the ethics review of health research is therefore less well regulated, especially for non-federally funded research in non-federal research organisations, than in South Africa. Non-federal institutions in the USA (and elsewhere) may choose to adopt the Common Rule and seek OHRP federal-wide assurance, but this is not mandatory unless authority to review US federally funded studies is sought. In contrast, the South African Health Act requires that all health-related (including social and behavioural) research conducted in South Africa must be reviewed by an REC that is registered with the NHREC, and must comply with the provisions of the South African Research Ethics guidelines ${ }^{7}$ and with the South African guidelines on good clinical practice (GCP). ${ }^{16}$ Two additional laws must also be complied with - the Children's Act ${ }^{17}$ and the Sexual Offences Act. ${ }^{18}$ We know of no federal law in the USA requiring mandatory registration of every IRB that reviews research with human participants.

These important differences suggest that there is generally wider mandatory oversight of health-related research in South Africa than in the USA. Philpott and Schüklenk's allegation that oversight in South Africa may be inferior is surprising in view of comments in an earlier editorial entitled 'Bioethical colonialism?'19 in which Chadwick and Schüklenk were critical of attempts by 'international agencies' to '... improve research ethics capacity in the developing world'. Now there is a paradoxical appeal from Philpott and Schüklenk ${ }^{1}$ to the same '... colonialist thinking ...' ${ }^{19}$ to impose superior US oversight on autonomous ethical review by an African country for studies such as the SAPIT study. ${ }^{2}$ 
Table III. Comparison of exemption sections of US Common Rule with South African law/ethics guidelines

\begin{tabular}{|c|c|c|}
\hline Ethical issue & US common law/ethics guidelines & SA law/ethics guidelines \\
\hline \multirow{18}{*}{$\begin{array}{l}\text { Protection of human research subjects } \\
\text { [Note: Exemptions are in (b) (1) though (5). } \\
\text { Sections (2) (4) and (5) differ between the } \\
\text { countries.] }\end{array}$} & Subpart A & National Health Act No. 61 of $2003^{12}$ \\
\hline & Basic HHS Policy for Protection of Human & (b) (2) (4) (5) require ethics approval \\
\hline & Research Subjects & \\
\hline & Authority: 5 U.S.C. $301 ; 42$ U.S.C. $289 ; 42$ & \\
\hline & U.S.C. $300 \mathrm{v}-1(\mathrm{~b})$. & \\
\hline & $\begin{array}{l}\text { Source: } 56 \text { FR 28012, 28022, } 18 \text { June 1991, } \\
\text { unless otherwise noted. }\end{array}$ & \\
\hline & '46.101 To what does this policy apply? & \\
\hline & $\begin{array}{l}\text { (a) Except as provided in paragraph (b) of } \\
\text { this section, this policy applies to all research } \\
\text { involving human subjects conducted, } \\
\text { supported or otherwise subject to regulation } \\
\text { by any federal department or agency which } \\
\text { takes appropriate administrative action to } \\
\text { make the policy applicable to such research ... }\end{array}$ & \\
\hline & $\begin{array}{l}\text { (b) Unless otherwise required by department } \\
\text { or agency heads, research activities in which } \\
\text { the only involvement of human subjects will } \\
\text { be in one or more of the following categories } \\
\text { are exempt from this policy: }\end{array}$ & \\
\hline & (1) $\ldots$ & \\
\hline & $\begin{array}{l}\text { (2) Research involving the use of educational } \\
\text { tests (cognitive, diagnostic, aptitude, } \\
\text { achievement), survey procedures, interview } \\
\text { procedures or observation of public behavior, } \\
\text { unless: }\end{array}$ & \\
\hline & $\begin{array}{l}\text { (i) information obtained is recorded in } \\
\text { such manner that human subjects can be } \\
\text { identified, directly or through identifiers } \\
\text { linked to the subjects; and }\end{array}$ & \\
\hline & $\begin{array}{l}\text { (ii) any disclosure of the human subjects' } \\
\text { responses outside the research could } \\
\text { reasonably place the subjects at risk of } \\
\text { criminal or civil liability or be damaging } \\
\text { to the subjects' financial standing, } \\
\text { employability, or reputation. }\end{array}$ & \\
\hline & (3) $\ldots$ & \\
\hline & $\begin{array}{l}\text { (4) Research involving the collection or } \\
\text { study of existing data, documents, records, } \\
\text { pathological specimens, or diagnostic } \\
\text { specimens, if these sources are publicly } \\
\text { available or if the information is recorded } \\
\text { by the investigator in such a manner that } \\
\text { subjects cannot be identified, directly or } \\
\text { through identifiers linked to the subjects. }\end{array}$ & \\
\hline & $\begin{array}{l}\text { (5) Research and demonstration projects } \\
\text { which are conducted by or subject to the } \\
\text { approval of department or agency heads, } \\
\text { and which are designed to study, evaluate, or } \\
\text { otherwise examine: }\end{array}$ & \\
\hline & (i) Public benefit or service programs; & \\
\hline & $\begin{array}{l}\text { (ii) procedures for obtaining benefits or } \\
\text { services under those programs; }\end{array}$ & \\
\hline
\end{tabular}


Table III. Comparison of exemption sections of US Common Rule with South African law/ethics guidelines (continued)

\begin{tabular}{|c|c|c|}
\hline Ethical issue & US common law/ethics guidelines & SA law/ethics guidelines \\
\hline & $\begin{array}{l}\text { (iii) possible changes in or alternatives to } \\
\text { those programs or procedures; or } \\
\text { (iv) possible changes in methods or levels } \\
\text { of payment for benefits or services under } \\
\text { those programs. } \\
\text { (c) ... } \\
\text { (d) ... } \\
\text { (e) ... } \\
\text { (f) ... } \\
\text { (g) This policy does not affect any foreign } \\
\text { laws or regulations which may otherwise } \\
\text { be applicable and which provide additional } \\
\text { protections to human subjects of research. } \\
\text { (h) When research covered by this policy } \\
\text { takes place in foreign countries, procedures } \\
\text { normally followed in the foreign countries } \\
\text { to protect human subjects may differ from } \\
\text { those set forth in this policy ... } \\
\text { In these circumstances, if a department or } \\
\text { agency head determines that the procedures } \\
\text { prescribed by the institution afford } \\
\text { protections that are at least equivalent to } \\
\text { those provided in this policy, the department } \\
\text { or agency head may approve the substitution } \\
\text { of the foreign procedures in lieu of the } \\
\text { procedural requirements provided in this } \\
\text { policy. }\end{array}$ & \\
\hline
\end{tabular}

\section{Background on research ethics training in South Africa}

In 2002 two applications for research ethics training grants from the Fogarty International Center of the National Institutes of Health were successful. The International Research Ethics Network of Southern Africa (IRENSA) (see http://www.irensa.org) was established at the University of Cape Town under Professor S Benatar, and SARETI (see http:shsph.up.ac.za/sareti.htm) was formed jointly at the universities of Pretoria and KwaZulu-Natal by Professors C IJsselmuiden and D Wassenaar in collaboration with the Johns Hopkins University, Berman Institute of Bioethics. While these both aim to increase research ethics capacity, they have different emphases. ${ }^{20} \mathrm{~A}$ third body, formed at the same time but without NIH support, was a Division of Bioethics at the University of the Witwatersrand headed by Professor U Schüklenk, now the Steve Biko Centre for Bioethics headed by Professor A Dhai (see http://web.wits.ac.za/Academic/Health/ Entities/Bioethics/).

In addition, all registered (licensed) health professionals in South Africa must obtain 30 continuing education units (CEUs) annually to maintain their professional registration, and at least 5 CEUs must be in professional ethics. South Africa also formally endorses the ICH (International Committee on Harmonisation) requirements for GCP in research, requiring that all investigators and senior personnel in clinical trials have valid GCP certification. There is an active GCP training environment in South Africa. The NHREC has recently taken steps to accredit GCP service providers to ensure that minimum standards are required when GCP certification is provided, and a process to set minimum training standards is currently underway.

Given this information, we contend that allegations that research ethics review in South Africa is sub-standard are ill informed and unsupported. Evidence suggests that with the promulgation of the current Health Act and the statutory oversight of the NHREC, requiring registration and compliance of all South African RECs, and ethics review of all health and related research in South Africa, there are fewer loopholes for the conduct of inadequately reviewed research than in many developed countries. ${ }^{21,22}$ Indeed several OHRP-approved RECs (IRBs) at several prestigious US institutions have been suspended over the past decade or more because of demonstrable harm to human participants, ${ }^{15,23-26}$ suggesting that human participant protection in the USA is not as superior as Philpott and Schüklenk argue.

Questions can still be asked about the quality of ethics review within a registered REC, but these are not unique to South Africa and are the subject of current global discussion - viz., what are valid performance indicators of competent ethics review procedures? The fact that a committee approves a controversial study is not necessarily a sign of incompetence; it may be the result of a careful consideration of equipoise, social value and scientific validity, and a careful risk/benefit determination. Questions can also be asked about the merits of conservative risk-avoidant ethics review processes that 
Table IV. Comparison of aspects of informed consent in the US Common Rule and South African law and guidelines

\begin{tabular}{|c|c|c|}
\hline Ethical issue & US Common Rule & SA law/ethics guidelines \\
\hline \multirow[t]{3}{*}{ Informed consent } & 46.116 Informed consent ${ }^{14}$ & \multirow{3}{*}{$\begin{array}{l}\text { Informed consent must adhere to the SA } \\
\text { Constitution }{ }^{11} \text { and the National Health } \text { Act }^{12} \\
\text { A waiver is possible only in some limited } \\
\text { circumstances for stored information }\end{array}$} \\
\hline & Waiver is possible if research involves & \\
\hline & $\begin{array}{l}\text { no more than minimal risk and the } \\
\text { waiver will not affect the rights and } \\
\text { welfare of subjects }\end{array}$ & \\
\hline \multirow[t]{6}{*}{ Documentation of informed consent } & $\begin{array}{l}\text { Waiver is possible if research could not } \\
\text { practicably be carried out without the } \\
\text { waiver }\end{array}$ & \\
\hline & $\begin{array}{l}\text { Waiver is possible if subjects will be } \\
\text { given additional pertinent information } \\
\text { after participation }\end{array}$ & \\
\hline & $\begin{array}{l}\text { Note: But local laws apply to make } \\
\text { consent legally effective }\end{array}$ & \\
\hline & $\begin{array}{l}\text { 46.117 Documentation of informed } \\
\text { consent }^{14}\end{array}$ & \multirow{3}{*}{$\begin{array}{l}\text { Written consent is the norm according to the } \\
\text { National Health Act; }{ }^{12} \text { verbal consent is the } \\
\text { exception }\end{array}$} \\
\hline & $\begin{array}{l}\text { For written consent information may } \\
\text { be read to a subject }\end{array}$ & \\
\hline & $\begin{array}{l}\text { Signed consent may be waived if this } \\
\text { could cause harm through breach of } \\
\text { confidentiality, if the research involves } \\
\text { no more than minimal risk and has no } \\
\text { procedures for which written consent } \\
\text { would normally be required }\end{array}$ & \\
\hline \multirow[t]{2}{*}{ Additional protection for children } & $\begin{array}{l}\text { Subpart D Additional protection for } \\
\text { children } 46.402 \text { Definitions }{ }^{14}\end{array}$ & \multirow[t]{2}{*}{$\begin{array}{l}\text { For research children are persons younger } \\
\text { than } 18 \text { years }\end{array}$} \\
\hline & $\begin{array}{l}\text { Children are persons who have not } \\
\text { attained the legal age for consent to } \\
\text { treatments or for procedures involved } \\
\text { in the research according to the } \\
\text { applicable law }\end{array}$ & \\
\hline
\end{tabular}

stifle socially valuable research and limit important developments in public health.

\section{Comparisons between some US federal regulations and legal/ethical requirements in South Africa}

Table III contrasts differences in waiver policy in the USA under the US Common Rule (45 CFR 46) ${ }^{14}$ and South African national guidance $^{7}$ and laws ${ }^{11,12}$ to indicate where more stringency is required in South Africa.

Surveys, interview procedures and behavioural studies, unless identifiable or potentially harmful, are exempted from ethics review in the USA in section (2) of 46.101 of the Common Rule. All of these types, whether in educational institutions or not, require ethical review in South Africa.

While the study of existing data in the public domain (section 4) is exempted in both countries, collection of other records must be cleared by an REC in South Africa. Under the same section, the Common Rule also exempts pathological and diagnostic specimens, which is not the case in South Africa. Should a researcher collect blood in a study that is granted ethical clearance in the USA, for example, he or she may share the sample with colleagues doing other research without clearance by an IRB (REC). Not so in South Africa, where each use of collected specimens must be scrutinised and approved by an REC in relation to the original protocol and informed consent. Recently the Havasupai Indian tribe successfully sued the University of Arizona for doing research other than the originally agreed diabetes mellitus investigation. ${ }^{27}$ The South African system prohibits similar unauthorised use of existing specimens.

Another important area of difference concerns informed consent (Table IV). The US Common Rule permits consent to be waived under several circumstances. In South Africa the possibility of a waiver is very limited. Similarly, there are differences in documentation of consent and age of consent for minors. In each instance the South African requirements are more stringent.

\section{Conclusion}

We fully agree with Boulle et al. ${ }^{4}$ that further training for RECs should be improved - however, this is a global issue and not unique to South Africa, which is relatively well resourced with research ethics training facilities. The SA NHREC guidelines require that all REC members receive initial and ongoing training in research ethics, so this point is uncontroversial. A more important point is to get RECs' host institutions globally to resource their RECs to better equip them to refine the complex balancing act of advancing important health research while maximising the protection of vulnerable participants.

While the points made above regarding the structural, legal and ethical requirements for ethics review of research in South Africa 
do not necessarily prevent poor-quality review from occurring, we argue that at a structural level ethics review in South Africa is in many cases equivalent to that provided by the US IRB and OHRP oversight system, and indeed is wider reaching and has no exclusions. The NHREC is soon to embark on a process of auditing all registered South African RECs, which will further ensure that the quality of review is at least equivalent to the best international standards.

Ms D Marais and Ms $\mathrm{N}$ Mamotte are thanked for bibliographical assistance.

1. Philpott S, Schüklenk U. A study that should not have been done. http://www.the hastingscentre.org/ Bioethicsforum/Post.aspx?id=4626\&blogid=140\#ixzz0nEEmxlUB (accessed 23 July 2010).

2. Abdool Karim SS, Nwaidoo K, Grobler A, et al. Starting antiretroviral therapy at three points in tuberculosis (SAPIT). N Engl J Med 2010;362:697-706.

3. Cohen J. Bioethicists assail a celebrated TB/HIV treatment trial. Science 2010;328:799-780.

4. Boulle A, Clayden P, Cohen K, et al. Prolonged deferral of antiretroviral therapy in the SAPiT trial: Did we need a clinical trial to tell us that this would increase mortality? S Afr Med J 2010;100:566-571.

5. Beecher HK. Ethics and clinical research. N Engl J Med 1966;274:1354-1360.

6. Medical Research Council (South Africa). Guidelines on ethics for medical research. Books 1-5. 20022004. http://www.sahealthinfo.org/ethics/index.htm (accessed 5 August 2010).

7. Department of Health, Pretoria. Ethics in health research: principles, structures and processes. 2004 http://www.doh.gov.za/nhrec/ (accessed 12 August 2010).

8. Human Sciences Research Council Code of Research Ethics. http://www.hsrc.ac.za/Corporate Information-6.phtml (accessed 12 August 2010).

9. Fletcher JC. Clinical bioethics at NIH: history and a new vision. Kennedy Institute of Ethics Journal 1995;5:355-364.

10. The Belmont Report. Ethical principles and guidelines for the protection of human subjects of research. http://ohsr.od.nih.gov/guidelines/belmont.html (accessed 12 August 2010).
11. Constitution of South Africa Act No. 108 of 1996. http://www.info.gov.za/documents/Constitution/ (accessed 12 August 2010).

12. National Health Act No. 61 of 2003. http://www.info.gov.za/documents/Acts/2003 (accessed 12 August 2010).

13. Office of Human Research Protections. http://hhs.gov/ohrp/ (accessed 12 August 2010)

14. US Code of Federal Regulations. Title 45 Public Welfare Department of Health \& Human Services. Part 46 Protection of Human Subjects (from July 14 2009). http://hhs.gov/ohrp/humansubjects/ guidance/ 45 cfr $46 . \mathrm{htm}$ (accessed 12 August 2010).

15. Gold J. Watching the watchdogs: negligence, liability, and research ethics boards. Health Law J 2003;11:153-176

16. Department of Health, Pretoria. Guidelines for good practice in the conduct of clinical trials in human participants in South Africa. 2nd ed. 2006. http://www.doh.gov.za/nhrec/ (accessed 12 August 2010).

17. Children's Act No. 38 of 2005. http://www.info.gov.za/documents/Acts/2005 (accessed 12 August 2010).

18. Criminal Law (Sexual Offences and Related Matters) Amendment Act 32 of 2007. http://www.info.gov. za/documents/Acts/2007 (accessed 12 August 2010)

19. Chadwick. R, Schüklenk U. Bioethical colonialism? Bioethics 2004;18:1467-8519 (online). http://www. biomedcentral.com/content/pdf/1472-6920-4-21.pdf (accessed 13 August 2010).

20. Benatar S. Research ethics coåmmittees in Africa: building capacity. PLoS Med 2007;4:e135. doi:10.1371/ journal.pmed.0040135 (accessed 13 August 2010).

21. Druml C, Wolzt M, Pleainer J, Singer EA. Research ethics committees in Europe: trials and tribulations. Intensive Care Med 2009;35:1636-1640.

22. Davies $\mathrm{H}$, Wells $\mathrm{F}$. Druml C. How can we provide effective training for research ethics committee members? A European perspective. J Med Ethics 2008;34:301-302.

23. Singh J. Research and legal liability. Acta Tropica 2009;112(S1):S71-S75.

24. Beasley DC. Coupling responsibility with liability: why institutional review board liability is good public policy. Northern Kentucky Law Review 2009;36:45-66.

25. Hoffman S, Berg JW. The suitability of IRB liability. University of Pittsburgh Law Review 2005;67:365427.

26. Powell DJ. Using the False Claims Act as a basis for institutional review board liability. University of Chicago Law Review 2002;69:1399-1426.

27. Mello MM, Wolf LE. The Havasupai Indian tribe case - lessons for research involving stored biologic samples. N Engl J Med 2010;63:204-207. 